\title{
EVALUASI SUPERVISI EKSTRAKURIKULER PAI SMPDI KECAMATAN KOKAP DAN PANJATANKABUPATEN KULON PROGO
}

\author{
Widodo \\ Program Studi Supervisi Pendidikan Agama Islam \\ Program Pasca Sarjana \\ Universitas Muhammadiyah Yogyakarta \\ E-mail: widodonada15@gmail.com
}

\begin{abstract}
Abstrak
Penelitian ini bertujuan untuk mengevaluasi supervisi ekstrakurikuler PAI SMP di Kecamatan Kokap dan Panjatan Kabupaten Kulon Progo. Evaluasi meliputi aspek desain, input, proses dan hasil supervisi ekstrakurikuler PAI. Jenis penelitian menggunakan metoda kualitatif dengan pendekatan diskriptif evaluatif dan data kualitatif model interaktif yang terdiri dari reduksi data, penyajian data dan kesimpulan. Responden dalam penelitian adalah pengawas madya PAI berjumlah 2 orang dan guru Pendidikan Agama Islam berjumlah 11 orang. Teknik pengumpulan data menggunakan observasi, wawancara, dan dokumentasi. Hasil penelitian menunjukan bahwa terdapat kesenjangan pada indikator desain supervisi, terdapat kesenjangan pada indikator input supervisi, terdapat kesenjangan pada indikator prosesdan hasil supervisi. Secara umum masih terjadi kesenjangan pada pelaksanaan supervisi ekstrakurikuler PAI SMP di Kecamatan Kokap dan Panjatan Kabupaten Kulon Progo. Maka direkomendasikan pelaksanaan dan tindak lanjut supervisi ekstrakurikuler PAI hendaknya dilaksanakan sesuai dengan program supervisi agar kualitas proses kegiatan ekstrakurikuler PAI di sekolah dapatt meningkat.
\end{abstract}

Kata kunci: evaluasi, supervisi ekstrakurikuler

\begin{abstract}
This study aims to evaluate the PAI extracurricular supervision at Junior High School in Kokap and Panjatan Subdistrict of KulonProgo Regency. This evaluation covers the design aspects, inputs, processes and results of PAI extracurricular supervision.The type of research used is using qualitative method using descriptive evaluative approach, and qualitative data interactive model consisting of data reduction, data presentation and conclusion. The respondents in this study were the PAI supervisor of middle school amounted to 2 people and the teacher of Islamic Religious Education which amounted to 11 people. Data collection techniques use observation, interviews, and documentation.The results of this study indicate that there are discrepancies of supervision desain indicators, there are discrepancies of supervision input indicators, there are discrepancies of supervision prosess and output indicators. In general there is still a gap in the implementation of PAI extracurricular supervision at Junior High School in Kokap and Panjatan Subdistrict of Kulon Progo Regency. Therefore, it is recommended to carry out PAI extracurricular supervision completely in accordance with the supervision program to improve the quality of the process of extracurricular activities of PAI in schools.
\end{abstract}

Key words: evaluation, extracurricular supervision

\section{Info Artikel}

Diterima September 2017, disetujui Oktober 2017, diterbitkan Desember 2017

Dipublikasikan Oleh: Program Studi Bimbingan dan Konseling 


\section{PENDAHULUAN}

Peraturan Menteri Agama (PMA) Nomor 16 Tahun 2010 tentang Peraturan Menteri Agama (PMA) Nomor 16 Tahun 2010 tentang Pengelolaan Pendidikan Agama dan Pendidikan Keagamaan pada Sekolah, Bab IV pasal 8 ayat 3 menyebutkan bahwa proses pembelajaran Pendidikan Agama dilakukan melalui intrakurikuler dan ekstrakurikuler. Ketentuan PMA tersebut adalah untuk seluruh proses pembelajaran pendidikan agama di sekolah termasuk proses pembelajaran Pendidikan Agama Islam (PAI).

Menurut Keputusan Menteri Agama Nomor 211 Tahun 2011 tentang Standar Nasional Pendidikan Agama Islam dijelaskan bahwa proses pembelajaran Pendidikan Agama Islam melalui dua proses kegiatan yaitu kegiatan intrakurikuler dan ekstrakurikuler Pendidikan Agama Islam (PAI). Proses kegiatan intrakurikuler dan ekstrakurikuler PAI dilaksanakan oleh semua satuan pendidikan dimaksudkan agar mutu PAI di sekolah sesuai dengan standar minimal yang di tetapkan.

Program kegiatan intrakurikuler dan ekstrakurikuler adalah sama pentingnya dan wajib dilaksanakan oleh satuan pendidikan sehingga hal tersebut mempunyai implikasi bahwa supervisi pengawas PAI terhadap dua macam proses kegiatan tersebut harus dilaksanakan secara seimbang. Kedua dasar hukum tersebut tidak membenarkan apabila program kegiatan intrakurikuler PAI lebih diutamakan dan harus mendapatkan pengawasan yang lebih dibandingkan program kegiatan ekstrakurikuler PAI.

Kegiatan ekstrakurikuler PAI menurut Kemenag R I (2009 : 3) memiliki fungsi pokok antara lain : (a) meningkatkan pengetahuan, penghayatan, pengalaman, dan pengamalan ajaran agama Islam kepada para siswa dalam kehidupan sehari-hari. (b) memberikan peluang kepada para siswa untuk mengembangkan dan mengekspresikan diri sesuai kebutuhan, bakat dan minat mereka sesuai dengan kondisi sekolahnya masing-masing.

Pengawas PAI bersama kepala sekolah dan guru PAI juga mempunyai peran dan tanggung jawab terhadap keterlaksanaan kegiatan ekstrakurikuler PAI ditingkat satuan pendidikan. Peraturan Direktur Jenderal Pendidikan Islam No. Dj.I/12A Tahun 2009 menyebutkan pelaksanaan kegiatan ekstrakurikuler PAI pada tingkat satuan pendidikan menjadi tugas dan tanggung jawab kepala sekolah, pengawas dan guru PAI.

Upaya mewujudkan peningkatan proses kegiatan ektrakurikuler PAI menuntut peran pengawas PAI secara intensif dalam memantau kegiatan ekstrakurikuler pada setiap sekolah dibawah binaannya. Peraturan Menteri Agama (PMA) Nomor 02 Tahun 2012 pasal 4 ayat 2c menjelaskan tentang 
fungsi/peran pengawas PAI adalah melakukan pemantauan standar nasional pendidikan. PMA ini merupakan salah satu instrumen hukum yang mengawali adanya kewenangan fungsi Pengawas PAI untuk melaksanakan urusan supervisi terhadap standar nasional PAI secara luas nyata dan bertanggung jawab. Hal tersebut berimplikasi pada perlunya Pengawas PAI untuk menyusun program, pelaksanaan pembinaan, pemantauan, supervisi, evaluasi, dan pelaporan kegiatan supervisi pendidikan khususnya dalam pemantauan standar proses pembelajaran PAI termasuk di dalamnya proses ekstrakurikuler PAI.

Dalam

kenyataannya, pelaksanaan supervisi akademik pengawas PAI termasuk didalamnya supervisi kegiatan ektrakurikuler PAI yang dilaksanakan di sekolah masih belum efektif. Hasil penelitian yang dilakukan Wahyu Imawati (2014) tentang "Evaluasi Supervisi Akademik dalam Meningkatkan Kompetensi Pedagogik Guru PAI SMA di Kabupaten Kulon Progo." Analisis penelitiannya menunjukkan bahwa masih ada indikator-indikator yang dikategorikan belum baik, seperti tujuan supervisi dikatagorikan cukup baik, guru mengkomunikasikan permasalahan dikatagorikan belum baik, perencanaan program pengawas dikategorikan belum baik, sosialisasi program dan pemetaan kebutuhan guru dikategorikan belum baik. Pelaksanaan, frekwensi, tindak lanjut supervisi dan hasil supervisi dikategorikan cukup baik. Hasil penelitian Wahyu Imawati ini mencerminkan bahwa pengawas sudah menjalankan peran dan fungsinya namun belum maksimal, terutama dalam menyusun program, pelaksanaan pembinaan, pemantauan, supervisi dan evaluasi.

Peran dan fungsi pengawas yang belum maksimal sangat berpengaruh dalam pelaksanakan supervisi ekstrakurikuler PAI di sekolah. Berdasarkan keterangan dari seorang guru PAI SMP diperoleh informasi awal bahwa Pengawas PAI dalam melakukan supervisi akademik menitik beratkan pada pelaksanaan proses pembelajaran intrakurikuler di dalam kelas, kadang-kadang hanya melakukan supervisi administrasi pembelajaran pada waktu awal semester saja. Fenomena ini mencerminkan bahwa supervisi kegiatan ektrakurikuler PAI di sekolah belum mendapatkan prioritas yang sama dengan kegiatan intrakurikuler PAI.

Terkait fenomena yang terjadi pada supervisi ekstrakurikuler PAI tersebut peneliti yakin bahwa banyak faktor lain yang dapatmempengaruhi pelaksanaan supervisiekstrakurikuler tidak sesuai dengan apa yang telah diprogramkan, dengan kata lain terjadi kesenjangan.

Fenomena inimelatarbelakangi peneliti untuk melakukan penelitian dengan judul "Evaluasi Supervisi Ekstrakurikuler 
PAI SMP di Kecamatan Kokap dan Panjatan Kabupaten Kulon Progo.”

Evaluasi menempati posisi yang sangat strategis dalam proses supervisi. Sedemikian penting evaluasi ini sehingga tidak ada satupun usaha untuk memperbaiki mutu supervisi yang dapat dilakukan dengan baik tanpa disertailangkah evaluasi. Model evaluasi pada penelitian ini adalah model kesenjangan (discrepancy model) yang dikembangkan oleh Malcolm Provus. Peneliti mempunyai pandangan terdapat kesenjangan antara program dengan pelaksanaan supervisi ekstrakurikuler PAI sehingga perlu mengukur besarnya kesenjangan yang seharusnya dicapai dengan kondisi riil. Kesenjangan yang diukur pada proses pembelajaran adalah kesenjangan antara proses yang dilaksanakan dibandingkan dengan standar supervisi yang telah ditetapkan. Aspek dan dimensi objek yang akan dievaluasi difokuskan pada evaluasi desain, input, konteks dan hasil supervisi kegiatan ekstrakurikuler PAI SMP di kecamatan Kokap dan Panjatan Kulon Progo.

\section{KAJIAN TEORI}

Menurut Keputusan Menteri Agama Nomor 211 Tahun 2011 tentang Standar Nasional Pendidikan Agama Islam dijelaskan bahwa proses pembelajaran Pendidikan Agama Islam melalui dua proses kegiatan yaitu kegiatan intrakurikuler dan ekstrakurikuler Pendidikan Agama
Islam (PAI). Kegiatan ekstrakurikuler PAI menurut Kemenag R I (2009 : 3) memiliki fungsi pokok antara lain : (a) meningkatkan pengetahuan, penghayatan, pengalaman, dan pengamalan ajaran agama Islam kepada para siswa dalam kehidupan sehari-hari. (b) memberikan peluang kepada para siswa untuk mengembangkan dan mengekspresikan diri sesuai kebutuhan, bakat dan minat mereka sesuai dengan kondisi sekolahnya masing-masing.

Hasil penelitian yang dilakukan Wahyu Imawati (2014) tentang "Evaluasi Supervisi Akademik dalam Meningkatkan Kompetensi Pedagogik Guru PAI SMA di Kabupaten Kulon Progo." Analisis penelitiannya menunjukkan bahwa masih ada indikator-indikator yang dikategorikan belum baik, seperti tujuan supervisi dikatagorikan cukup baik, guru mengkomunikasikan permasalahan dikatagorikan belum baik, perencanaan program pengawas dikategorikan belum baik, sosialisasi program dan pemetaan kebutuhan guru dikategorikan belum baik. Pelaksanaan, frekwensi, tindak lanjut supervisi dan hasil supervisi dikategorikan cukup baik. Hasil penelitian Wahyu Imawati ini mencerminkan bahwa pengawas sudah menjalankan peran dan fungsinya namun belum maksimal, terutama dalam menyusun program, pelaksanaan pembinaan, pemantauan, supervisi dan evaluasi. 


\section{METODE PENELITIAN}

Menurut Cresswell (2013: 2122) ada lima jenis penelitian kualitatif, yaitu : (1) etnografi, (2) Grounded Theory, (3) studi kasus, (4) fenomenologi, (5) naratif.

Jenis penelitian yang akan digunakan oleh peneliti dalam penelitian ini adalah studi kasus.Menurut Pawito ( 2007: 141) studi kasus intinya adalah meneliti kehidupan satu atau beberapa komunitas, organisasi atau perorangan yang dijadikan unit analisis, dengan menggunakan pendekatan kualitatif.

Menurut Stake dalam Cresswell (2013:22), studi kasus merupakan strategi penelitian dimana di dalamnya peneliti menyelidiki secara cermat suatu program, peristiwa, aktivitas, proses atau sekelompok individu. Kasus-kasus dibatasi oleh waktu dan aktivitas, dan peneliti mengumpulkan informasi secara lengkap dengan menggunakan berbagai prosedur pengumpulan data berdasarkan waktu yang telah ditentukan.Dengan demikian, studi kasus merupakan penelitian dimana peneliti menggali suatu fenomena tertentu (kasus) dalam waktu tertentu dan kegiatan ( program, even, proses, institusi atau kelompok sosial ) serta mengumpulkan informasi secara terinci dan mendalam dengan menggunakan prosedur pengumpulan data selama periode tertentu. Dalam penelitian ini peneliti ingin meneliti fenomena yang terjadi pada pelaksanaan supervisi pengawas PAI pada kegiatan ekstrakurikuler di SMP
Kecamatan Kokap dan Panjatan Kulon Progo.

Penelitian dilaksanakan di SMP wilayah Kecamatan Kokap dan Panjatan Kabupaten Kulon Progo. Waktu efektif penelitian dilaksanakan mulai bulan April sampai dengan bulan Juni tahun 2017.

Subyek penelitian yang dimaksud adalah nara sumber atau informan sebagai sumber dimana data dapat diperoleh dan dipandang mengetahui pelaksanaan supervisi pengelolaan kegiatan esktrakurikuler PAI di lokasi penelitian. Peneliti menggunakan teknik purposive sampling dalam memilih informan, yakni informan yang dipilih adalah orang yang dianggap tahu dan dapat dipercaya sebagai sumber data. Nara sumber terdiri dari Pengawas PAIsekolah menengah sebanyak 2 orangdan Guru PAISMP 11 orang yang berada di wilayah kecamatan Kokap dan Panjatan Kabupaten Kulon Progo. Sedangkan obyek penelitian ini adalah pelaksanaan supervisi pengawas PAI pada kegiatan ekstrakurikuler PAI SMP di Kecamatan Kokap dan Panjatan Kabupaten Kulon Progo tahun pelajaran 2016/2017.

Kriteria evaluasi diperlukan sebagai penentuan keberhasilan program. Setiap variabel program dianggap baik atau tidak ada kesenjangan jika memenuhi syaratsyarat yang mencakup kawasan indikator-indikator. Dalam kegiatan supervisi ekstrakurikuler PAI SMP di 
kecamatan Kokap dan Panjatan Kabupaten Kulon Progo, kriteria yang diperlukan adalah : (1) Kriteria desain, kriteria ini dengan indikator tujuan supervisi supervisi ekstrakurikuler PAI, kesiapan instrumen, guru dan kelengkapan supervisi, penetapan standar kriteria, harapan pengawas dan guru dengan adanya supervisi serta perencanaan program supervisi. Desain dikatakan baik bila benarbenar semua indikator terpenuhi untuk membantu terhadap kebutuhan guru dalam proses kegiatan ekstrakurikuler PAI. (2) Kriteria input, kriteria ini menunjukkan kesiapan pengawas dalam mensupervisi melalui kualitas dan kuantitas dengan indikator sumber daya manusia (SDM), sosialisasi program, pemetakan kebutuhan guru, sarana prasarana, karakterisitik guru dan materi-materi program supervisi . Input ini dikatakan baik jika semua indikator terpenuhi untuk meningkatkan kemampuan guru dalam mengelola ektrakurikuler PAI. (3) Kriteria Proses, Kriteria ini meliputi indikator pelaksanaan supervisi, cara supervisi, frekwensi supervisi, metode supervisi, tindak lanjut atau solusi dan hubungan pengawas dengan guru. Kriteria proses dikatakan baik jika semua indikator terpenuhi untuk meningkatkan kualitas proses kegiatan ekstrakurikuler PAI. (4) Kriteria Produk, kriteria ini dikatakan baik jika supervisi ekstrakurikuler PAI mampu meningkatkan kualitas proses ekstrakurikuler PAI dengan indikator guru dapat membuat program ekstrakurikuler PAI dan melaksanakan kegiatan ektrakurikuler PAI di sekolah dengan maksimal.

Jenis dan sumber data dalam penelitian ini berupa data primer merupakan data yang diperoleh secara langsung dari informan penelitian. Data ini diperoleh melalui hasil wawancara dan hasil observasi. Sumber data primer adalah pengawas PAI, Guru PAI, yang terlibat dalam pelaksanaan supervisi pengawas PAI pada kegiatan ekstrakurikuler di SMP kecamatan Kokap dan Panjatan Kabupaten Kulon Progo.Data sekunder merupakan data yang diperoleh dari dokumen atau literatur. Dalam penelitian ini data sekunder diperoleh melalui dokumen yang berkaitan dengan pelaksanaan supervisi pengawas PAI pada kegiatan ektrakurikuler PAI di SMP Kecamatan Kokap dan Panjatan Kabupaten Kulon Progo.

Teknik pengumpulan data dalam penelitian ini adalah : Observasi, wawancara dan studi dokumentasi. Teknik observasi penelitian dilakukan dengan menggunakan dua cara observasi yaitu observasi nonsistematis dan observasi sistematis. Menurut Suharsimi Arikunto (2010: 157) observasi non-sistematis tidak menggunakan instrumen pengamatan, sedangkan observasi sistematis dengan menggunakan pedoman sebagai instrumen pengamatan.Observasi non sistematis dilakukan untuk mengetahui kondisi obyektif kegiatan ektrakurikuler PAI di sekolah sebelum 
\begin{tabular}{lrr}
\multicolumn{2}{l}{ disupervisi,sedangkan } & observasi \\
sistematis & dilaksanakan & untuk \\
memperoleh & informasi & data
\end{tabular} pelaksanaan supervisi administratif guru, teknik supervisi, kemampuan pengawas melaksanakan supervisi dan hasil supervisi ekstrakurikuler PAI yang dilakukan pengawas di Sekolah. pengamatan dilakukan pada waktu kegiatan kepengawasan sedang berjalan pada aspek perilaku yang tampak pada subyek yang akan diteliti. Observasi dilakukan oleh peneliti terjun langsung ikut dalam kegiatan (partisipant observation) bersama pengawas dalam pelaksanaan supervisi.

Suharsimi Arikunto (2010:155) menjelaskan wawancara/ interviu digunakan untuk menilai keadaan seseorang. Secara fisik interviu dibedakan atas interviu terstruktur dan interviu tidak terstruktur. Dalam penelitian wawancara dilakukan pada orang yang dianggap representatif dan dapat memberikan informasi yang valid atas data-data yang diperlukan. Wawancara dilakukan terhadap pengawas PAI dan Guru-guru PAI SMP untuk menggali data mengenai pelaksanaan supervisi pengawas PAI, keterlibatan pengawas PAIdan guru PAI serta kondisi obyektif kegiatan ekstrakurikuler PAI.

Data (informasi) yang diperlukan dalam penelitian ini juga diperoleh melalui studi dokumentasi, Burhan Bungin (2008: 155) mengartikan studi dokumentasi yaitu pengumpulan data dengan cara mencari atau menelaah data tentang hal-hal yang relevan dalam penelitian ini yang bersumber dari bahan-bahan tertulis, foto-foto, $C D$, film, harddisk, dan sebagainya.Data dalam penelitian dikumpulkan dengan menggunakan studi dokumen pada komponen perencanaan supervisi, observasi pada komponen pelaksanaan supervisi dan hasil supervisi.

Untuk menguji keabsahan data dalam penelitian ini menggunakan triangulasi sumber dan metode.Trianggulasi sumber dilakukan dengan membandingkan dan mengecek ulang derajat kepercayaan suatu informasi yang diperoleh melalui sumber yang berbeda, dalam hal ini semua data diperoleh dari pengawas PAI, kepala sekolah, guru PAI dan peserta didik.Triangulasi metode dilakukan dengan membandingkan dan mengecek ulang derajat kepercayaan suatu informasi yang diperoleh melalui metode pengumpulan data yang berbeda, dalam hal ini suatu data atau informasi diperoleh melalui observasi, wawancara, dan dokumentasi.

Analisis data menggunakan teknik analisis diskriptif kualitatif. Dengan teknik ini interprestasi terhadap data dibuat dan disusun secara sistematis dan sistemik tentang obyek yang diteliti, dilakukan bersamaan dengan proses pengumpulan data. Dalam penelitian ini analisis data menggunakan model Miles dan Huberman (1992: 20), 
yakni analisis data dengan komponen data reduction, data display, dan conclusion drawing/verification. Langkah -langkahnya sebagai berikut: (1) Data reduction atau reduksi data, yaitu proses merangkum, memilahmilah yang pokok, memfokuskan pada hal-hal yang penting dan mencari tema serta polanya sehingga dapat memberi gambaran yang jelas. (2) Data display atau penyajian data, yaitu mengorganisasi data dan menyususun pola hubungan sehingga data mudah dipahami dalam penyajian data ini dilakukan coding untuk dapat mengorganisasi dan mensistematisasi data yang lengkap dan detail sehingga dapat memunculkan data tentang topik yang diteliti. Coding juga bertujuan untuk mengelompokkan data sesuai dengan sumber dan jenisnya. (3) Conclusion/verifying atau penarikan kesimpulan, yaitu kesimpulan dari verifikasi atas pola keteraturan dan penyimpangan yang ada dalam fenomena yang muncul pada program supervisi pada kegiatan ekrtakurikuler PAI di Kecamatan Kokap dan Panjatan Kulon Progo.

\section{HASIL PENELITIAN DAN PEMBAHASAN}

Supervisi ekstrakurikuler PAI SMP di Kecamatan Kokap dan Panjatan Kabupaten Kulon Progo dievaluasi dengan model Descrepancy.

\section{Evaluasi desain}

Evaluasi desain supervisi adalah kesesuaian antara tujuan yang diharapkan pengawas dalam proses supervisi dengan kebutuhan guru dalam proses kegiatan ekstrakurikuler PAI. Hal ini diwujudkan dalam bentuk perencanaan program supervisi. Evaluasi desain meliputi (1) indikator tujuan supervisi ekstrakurikuler PAI; (2) Kesiapan instrumen, guru dan kelengkapan supervisi (3) penetapan standar kriteria keberhasilan supervisi (4) harapan pengawas dan guru dengan adanya supervisi; dan (5) perencanaan program supervisi.

Desain pada indikator tujuan supervisi ekstrakurikuler PAI SMP Kecamatan Kokap dan Panjatan Kulon Progoterdapat kesenjangan. Tujuan supervisi sebagaimana tertulis dalam program tahunansupervisi adalah untuk mengetahui kemampuan guru PAI mengelola kegiatan ekstrakurikuler PAI. Tujuan supervisi ekstrakurikuler PAI tersebut dimaksudkan untuk memberikan arah pembinaan secara tepat terhadap guru agar dalam mengelola ekrakurikuler lebih baik. Sejalan dengan hal tersebut Suharsimi Arikunto (2010 :40) menegaskan bahwa tujuan supervisi adalah memberikan bantuan teknis dan bimbingan kepada guru ( dan staf sekolah yang lain) agar personil tersebut mampu meningkatkan kualitas kinerjanya, terutama dalam melaksanakan tugas, yaitu proses pembelajaran. Hasil penelitian menunjukkan bahwa tujuan supervisi 
ekstrakurikuler PAI terdapat kesenjangan, tujuan supervisi yang di tuangkan dalam program supervisi masih mengulang seperti tujuan supervisi pada tahun-tahun sebelumnya. Pengawas belum memiliki target yang spesifik dengan menetapkan kriteria supervisi ektrakurikuler PAI dalam meningkatkan kualitas proses kegiatan ekstrakurikuler PAI di sekolah.

Desain supervisi pada indikator kesiapan instrumentidak terdapat kesenjangan, guru dan kelengkapan supervisi. Pengawas PAI ketika akan melaksanakan supervisi telah menyiapkan kelengkapan dan instrumen dengan lengkap baik berupa sarana-prasarananya maupun manusia sebagai sumber informasi data.Kelengkapan supervisi berupa program supervisi seperti program tahunan, program semester, dan RKA. Instrumen supervisi meliputi instrumen pencermatan, instrumen pengamatan, buku journal supervisi dan buku bimbingan guru. Kelengkapan sarana prasarana supervisi seperti ruang tamu atau kelas dan alat tulis kantor. Kelengkapan yang berupa manusia adalah siswa yang belajar, guru PAI, siswa, Kepala Sekolah maupun guru lain di sekolah tersebut yang dapat memberikan informasi dan data untuk kegiatan supervisinya. Hal tersebut sesuai dengan penjelasan Binti Maimunah (2009: 127) bahwa informasi data meliputi komponen siswa, guru, kurikulum, sarana prasarana, pengelolaan dan lingkungan. Pengawas PAI telah menjalankan fungsinya dengan maksimal dengan persiapan instrumen yang maksimal maka pemantauan standar nasional pendidikan sebagai mana diamanahkan dalam PMA No 2 tahun 2012 Pasal 2 (c) dapat berjalan optimal.

Desain supervisi pada penetapan standar kriteria keberhasilan tidak terdapat kesenjangan.Semua Pengawas PAI sekolah menengah Kabupaten Kulon Progo sepakat dalam menentukan standar kriteria keberhasilan supervisi ekstrakurikuler PAI yakni semua atau $100 \%$ guru PAI memiliki program ekstrakurikuler PAI dan melaksanakannya. Penetapanstandar kriteria didasarkan tanggung jawabnya atas kualitas perencanaan dan proses hasil kegiatan pendidikan. Sebagaimana Fanseth Jane dan Ayesr, Fren E. Dalam bukunya Piet Sahertian (2000: 25) menganggap bahwa supervisi bertujuan untuk memelihara program pengajaran yang ada sebaik-baiknya sehingga ada perbaikan. Standar kriteria keberhasilan supervisi ekstrakurikuler tersebut dituangkan dalam program tahunan, program semester dan rencana kepengawasan akademik (RKA).Standar kriteria keberhasilan supervisi ekstrakurikuler PAI yang di buat oleh pengawas PAI sudah sesuai dengan fungsi dan tanggung jawab pengawas PAI, yakni fungsinya dalam pemantauan penerapan standar nasional PAI dalam 
hal ini adalah standar proses kegiatan ektrakurikuler PAI dan tanggung jawabnya dalam terhadap peningkatan kualitas perencanaan, proses, dan hasil pendidikan dan/atau pembelajaran PAI di sekolah sesuai PMA nomor 12 tahun 2012 pasal 5 ayat 2.Indikator keberhasilan, ditulis secara jelas dan terukur sesuai dengan tujuan pembinaan dinyatakan dalam prosentase.

Desain supervisi pada indikator harapan pengawas dan guru tidak terdapat kesenjangan dengan adanya supervisi. Pengawas dan guru PAI sependapat untuk meningkatkan kinerjanya melalui proses pelaksanaan supervisi. Piet Sahertian (2000: 24) berkeyakinan bahwa supervisi akan dapat memberi bantuan terhadap program pendidikan melalui bermacam-macam cara sehingga kualitas kehidupan akan dapat diperbaiki karenanya. Pengawas dan guru sependapat bahwa adanya supervisi membantu peningkatan kompetensi guru dan keberhasilan pencapaian tujuan ekstrakurikuler PAI.

Desain supervisi pada indikator perencanaan program supervisi ekstrakurikuler PAI terdapat kesenjangan dimana Pengawas dalam menyusun perencanaan program supervisi ekstrakurikuler PAI tidak pernah melibatkan guru. Keterlibatan peran guru hanya pada pendataan ketika pengawas mensupervisi dan melakukan identifikasi masalahmasalah guru.Supervisi ekstrakurikuler PAI merupakan tanggung jawab bersama antara pengawas dan guru, apabila guru dilibatkan mengidentifikasi masalahmasalahnya maka supervisi ekstrakurikuler PAI akan benar-benar sesuai yang dibutuhkan guru dan masalah yang dihadapinya akan teratasi. Maka alangkah baiknya jika programnya di desain bersama oleh pengawas dan guru sehingga dengan adanya program supervisi ekstrakurikuler yang realitik sesungguhnya dapat menolong pengawas melakukan pembinaan yang progresif dan akumulatif artinya para pengawas diharapkan terhindar dari penanganan masalah yang sama dari waktu-kewaktu. Sehingga tanggun jawabnya dapat maksimal seperti yang diamanahkan PMA nomor 12 tahun 2012 pasal 4 ayat 2 (a).

\section{Evaluasi input}

Input supervisi ekstrakurikuler PAI adalah kesiapan pengawas untuk melakukan supervisi ektrakurikuler PAI dan guru sebagai pihak yang disupervisi. Evaluasi input meliputi: (1) SDM pengawas; (2) sosialisasi program supervisi; (3) materi-materi supervisi yang dipersiapkan pengawas dalam meningkatkan kualitas proses kegiatan ekstrakurikuler PAI. (4) sarana-prasarana; (5) karakterikstik guru; (6) pemetakan kebutuhan guru;

Komponen input, pada indikator SDM pengawas tidakterdapat kesenjangan. Pengawas PAI tingkat menengah di kulon Progo kompeten 
dibuktikan dengan tingkat pendidikan minimal S1 dan pengalaman masa kerja menjadi guru PAI minimal 17 tahun sebelum menjadi pengawas ditambah diklat-diklat yang pernah diikutinya. Tidak ada kesenjangan dalam masalah SDM pengawas karena tingkat pendidikan dan masa kerja yang sudah lama mendukung kompetensi yang dimiliki oleh seorang pengawas sehingga dapat mendukung kompetensinya seperti amanah PMA no 2 tahun 2012 pasal 8 ayat 1 dan 2 .

Input pada indikator sosialisasi program supervisi oleh pengawas PAI terdapat kesenjangan. Sosialisasi yang dilakukan pengawas PAI masih berupa pembinaan terhadap guru PAI yang berkaitan dengan aturan-aturan dan kebijakan baru tentang PAI. Pengawas tidak melakukan sosialisasi program-program supervisi ekstrakurikuler PAI seperti yang dijadwalkan dalam programnya. Sehingga terjadi kesenjangan antara harapan guru dan pengawas tidak pernah sampai karena kurangnya komunikasi diantara mereka. Sehingga terjadi kesenjangan antara harapan dengan kenyataan yang tidak pernah terealisasi. Menurut Binti Maimunah (2009: 154) banyak kendala sosialisasi dari pembinaan yang minim diantaranya adalah sistem pembinaan yang kurang memadai seperti kurangnya tatap muka, kurangnya penambahan pengetahuan baru bagi guru, supervisi lebih menekankan aspek administratif.
Input dengan indikator pada materi-materi kepengawasan supervisi untuk meningkatkan kualitas proses kegiatan ekstrakurikuler PAI terdapat kesenjangan. Pengawas telah membuat RKA dengan aspek masalah pembinaan, pemantauan dan penilaian GPAI dalam pelaksanaan ekstrakurikuler PAI. Realisasi dilapangan materi-materi supervisi masih bersifat umum belum berupa bimbingan yang bersifat khusus untuk meningkatkan kualitas proses kegiatanekstrakurikuler PAI di sekolah.

Input dari indikator sarana dan prasarana tidak ada kesenjangan karena tempat pengawas dalam melakukan supervisi kegiatan ekstrakurikuler adalah sekolah tempat guru PAI bertugas dan MGMP. Pengawas melakukan supervisi individual dengan melakukan kunjungan langsung ke sekolah dan supervisi secara kelompok dan dsi sesuaikan kondisi melalui pertemuan MGMP. Pengawas PAI melakukan pembinaan secara kelompok dalam MGMP tidak secara periodik dan terjadwal. Faktor utama dalam kurangnya penyelenggaraan pembinaan adalah berkaitan pelaksanaan supervisi individual yang ada diprogam kepengawasan yang harus dilaksanakan sehingga memerlukan waktu yang cukup panjang sehingga pengawas belum maksimal menggunakan MGMP sebagai sarana pembinaan dalam pelaksanaan kepengawasannya. 
Kondisi ini sisebabkan karena rasio jumlah pengawas dan guru yang tidak seimbang sehingga pengawas mempunyai beban kerja yang lebih berat. Jumlah pengawas 2 orang dengan guru binaan sejumlah 162 guru, rasio 1:81dengan tuntutan kinerja 37,5 jam perminggu. Pengawas sudah berusaha menggunakan MGMP sebagai sarana supervisinya sesuai dengan yang telah diprogramkan.

Input dari indikator karakteristik guru tidak ada kesenjangan dan dikategorikan sangat baik. Guru PAI SMP di kecamatan Kokap dan Panjatan memiliki berkepribadian baik, bersikap responsif dan aktif dengan adanya supervisi sebagian besar guru merasa senang karena kedatangan pengawas merupakan bentuk perhatian terhadap guru, guru merasa diposisikan sebagai patner kerja bukan bawahan, pengawas dianggap sebagai orang yang mampu memberikan pembinaan, motivasi dan perbaikan kinerja guru.

\section{Evaluasi proses}

Evaluasi proses dalam penelitian ini bertujuan untuk mengetahui pelaksanaan supervisi kegiatan ekstrakurikuler PAI yang dilakukan oleh pengawas untuk meningkatkan proses kegiatan ekstrakurikuler PAI SMP di kecamatan Kokap dan Panjatan Kulon Progo meliputi : (1) indikator cara supervisi; (2) frekwensi supervisi; (3) Metode supervisi; (4) tindak lanjut; (5) hubungan dengan guru.

Proses pada indikator cara supervisi terdapat kesenjangan Pelaksanakan supervisi proses kegiatan ekstrakurikuler PAI tidak lebih pada supervisi secara administratif saja sedang pemantauan proses hanya memastikan kegiatan btersebut berjalan atau tidak. Carasupervisi proses kegiatan ekstrakurikuler yang berbeda dengan proses kegiatan intrakurikuler ini disebabkanyang menjadi obyek pemantauan kegiatan adalah pembimbing ekstrakurikuler dari luar sekolah yang berkompeten dibidangnya tidak berlatarbelakang sebagai seorang guru PAI. Salah satu tugas pokok dan fungsi pengawas adalah membina, membimbing dan pengembangan profesi guru GPAI sesuai pasal 4 ayat 2 (a) PMA no 12 tahun 2011. Pembimbing ekstrakurikuler selain guru PAI maka adalah diluar tugas dan tanggung jawanya, namun begitu karena kegiatan ekstrakurikuler PAI dibawah tanggung jawab guru PAI maka pengawas harus tetap melaksanakan fungsimya untuk memantau proses kegiatan ekstrakurikuler PAI sebagai bagian dari tanggung jawabnya yakni memantau penerapan standar nasional PAI sesuai pasal 4 ayat 2(c).

Proses pada indikator Frekwensi supervisi ekstrakutrikuler PAI terdapat kesenjangan. Pengawas PAI belum sesuai dengan SPM (Standar Pelayanan Minimal) satu bulan satu 
sekolahan dengan waktu bimbingan 3 (tiga) jam. Jumlah pengawas PAI tingkat menengah Kulon Progo sebanyak 2 orang harus mengawasiguru PAI binaannya sebanyak 162 orang merupakan beban terlalu berat bagi kinerja pengawas. Kurang idealnya jumlah pengawas dan guru PAI yang disuprvisi pengawas sehingga membuat prioritas-prioritas sekolah yang disupervisi. Kondisi demikian menjadikan frekwensi supervisi tidak sesuai Standar Pelayanan Minimal.

Proses pada indikator Pemakaian metode dalam teknik supervisi terdapat kesenjangan. Metode supervisi yang digunakan Pengawas masih sangat terbatas. Teknik individual belum menggunakan metode kunjungan kelas, kunjungan antar kelas, dan penilaian diri sesuai pendapat Gwyn dalam Maimunah (2009: 29) bahwa kunjungan kelas, kunjungan antar kelas dan penilaian diri termasuk dalam metode dalam teknik individual dalam supervisi. Demikian juga pengawas dalam melaksanakan teknik supervisi kelompok baru menggunakan dua macam metode yaitu pertemuan guru dan kepanitiaankepanitiaan.Pengawas menggunakan metode dalam pelaksanaan supervisi masih sama setiap tahunnya dan dikategorikan baik. Penggunaan metode dalam teknik supervisi pengawas harus berkembang karena berhubungan dengan penyelesaian masalah-masalah guru dalam melaksanakan kegiatan ekstrakurikuler PAI. hal tersebut senada dengan pendapat Binti maimunah (2009: 30) bahwa supervisi dapat dilakukan dengan berbagai cara agar apa yang diharapkan bersama dapat menjadi kenyataan.

Proses pada indikator tindak lanjut supervisi terdapat kesenjangan. Pengawas menuliskan dalam program tahunan supervisi kegiatan ekstrakurikuler meliputi pendampingan dan pembimbingan, demikian juga dalam dokumen RKA memuat komponen rencana tindak lanjut yaitu pembinaan dan arahan tentang program /pelaksanaan kegiatan ekstrakurikuler PAI serta penentuan materi ekstrakurikuler selanjutnya.Pengawas PAI telah membuat program kepengawasan yang maksimal dengan memuat komponen tindak lanjut dalam supervisinya mengawas telah melaksanakan fungsinya yaitu menyusun program pengawasan PAI sesuai amanah pasal 4 ayat 2 (a) PMA nomor 2 tahun 2012.Pengawas tidak melakukan tindak lanjut untuk solusi pelaksanaan kegiatan ektrakurikuler di sekolah pada pertemuan berikutnya. Pengawas belum melakukan dindak lanjut supervisi dengan menindaklanjuti supervisi berikutnya untuk memperpaiki kekurangan guru. pengawas tidak pernah mengkroscek solusi yang ditawarkan untuk dilaksanakan oleh guru pada pertemuan berikutnya dengan melakukan supervisi kembali. 
Proses pada indikator hubungan Pengawas dengan guru. Pengawas adalah mitra kerja guru dalam meningkatkan kegiatan ekstrakurikuler PAI di sekolah agar efektif sehingga perlu kerjasama secara efektif. Kemitraan dan saling keterbukaan yang dilandasi dengan pendekatan yang komunikatif secara informal. Sikap guru menjadi indikasi hubungan pengawas dan guru yang harmonis. Sebagian besar guru merasa senang dengan kehadiran pengawas. Perbaikan atau peningkatan mutu pengajaran disekolah berkaitan erat dengan proses supervisi. Sesuai pendapat Binti Maimunah, pada masalah ini sudah seharusnya supervisor yang merupakan unsur penting bagi keefektifan layanan supervisi mendorong guru agar berupaya mendorong peningkatan diri sendiri.Observasi dan tatap muka adalah suatu wahana yang dapat dipergunakan untuk mendapatkan perbaikan penampilan mengajar karena itu supervisor diharapkan mampu merumuskan perhatian guru melalui pertemuan pengamatan (observasi) tertentu dan sspesifik dengan harapan memperoleh minat dan keinginan untuk membantu terjadinya perubahanyang lebih baik.

Kindsvatter dan Willen menjelaskan dalam bukunya Binti maimunah (2009: 127) bahwa observasi dan pertemuan supervisi pada hakikatnya dapat menyebabkan berbagai bentuk kecemasan atau ketakutan terhadap guru. supervisor (kepala sekolah) hendaknya mampu mengembangkan yang memungkinkannya memahami kecemasan-kecemasan itu, jika mengabaikannya maka hasil positif supervisi akan sulit dicapai. Disinilah letak komunikasi interpersonal selama pertemuan supervisi yang diharapkan memberi dampak perbaikan dalam kegiatan pembelajaran baik yang segera dapat diamati maupun untuk penampilan yang akan datang.

\section{Evaluasi hasil}

Evaluasi hasil supervisi ekstrakurikuler PAI adalah keterlaksanaan secara optimal kegiatan ekstrakurikuler PAI SMP di wilayah kecamatan Kokap dan panjatan Kulon Progo oleh semua guru PAI. Standar acuan yang dipakai peneliti untuk evaluasi hasil adalah komponen dalam instrumen supervisi kegiatan ekstrakurikuler PAI pengawas. Indikator keberhasilan sesuai dengan program tahunan pengawas tahun 2016-2017 meliputi: (1) semua guru membuat program kegiatan ekstrakurikuler PAI; (2) semua guru melaksanakan kegiatan ekstrakurikuler PAI.

Hasil pada indikator pembuatan program ekstrakurikuler PAI oleh guru terdapat kesenjangan. Data Penelitian menujukkan dari 6 guru PAI pada SMP negeri 2 diantaranya telah melaksanakan kewajiban dan tugasnya menyusun semua administrasi program ekstrakurikuler PAI sedangkan 4 guru baru membuat 
sebagian program. Sedangkan dari 5 orang guru PAI yang mengajar pada SMP swasta telah membuat sebagian program satu orang guru telah menyusun semua prgram ekstrakurikuler PAI dan 4 orang yang lainnya telah membuat sebagian program. Data tersebut dimaknai bahwa sebagian besar guru PAI belum membuat semua program Esktrakurikuler PAI. Data yang demikian tersebut menunjukkan terdapat kesejenjangan antara program pengawas PAI dengan realisasi yang ada di lapangan. Dalam program tahunan dan RKA di targetkan bahwa semua guru PAI mempunyai program ekstrakurikuler dan mampu melaksanakannya.Realisasi

dilapangan belum semua guru PAI membuat program ekstrakurikuler PAI seperti yang diharapkan oleh pengawas, dari 11 guru PAI baru 3 guru yang membuat program ekstrarikuler PAI lengkap.

Hasil pada indikator
pelaksanaan kegiatan ekstrakurikuler belum maksimal. Data yang diperoleh menggambarkan bahwa Guru PAI SMP di kecamatan Kokap dan Panjatan sebagian telah melaksanakan kegiatan ekstrakurikuler PAI di sekolah. Pengawas PAI menuliskan 10 (sepuluh) kegiatan ektrakurikuler PAI dalam instrumen supervisinya meliputi : jabat tangan/ucap salam, tadarus pagi, shalat Dhuha, jamaah Dhuhur/Jum'at, pesantren Ramadhan, Tuntas Baca Tulis al-Qur'an (TBTQ), PHBI, wisata rohani, ROHIS dan pentas seni Islam. Terdapat 9 SMP baik negeri maupun swasta di wilayah kecamatan Kokap dan Panjatan semua telah melaksanakan kegiatan ekstrakurikuler PAI berupa kegiatan berjabat tangan/ucapan salam, pesantren ramadhan, Tuntas Baca Tulis al-Qur'an dengan perolehan nilai untuk ke 5 sekolah negeri dengan nilai sangat baik sedangkan 4 sekolah swasta dengan nilai cukup. Pada kegiatan tadarus pagi, shalat dhuha dan shalat Dhuhur/Jum'at berjamaah dilaksanakan oleh semua sekolah negeri dengan perolehan nilai sangat baik, kegiatan Peringatan Hari Besar Islam (PHBI) dilaksanakan oleh 2 sekolah negeri sedang kegiatan wisata rohani, ROHIS dan pentas seni Islam tidak dilaksanakan oleh semua sekolah baik negeri maupun swasta.

Kurang maksimalnya hasil supervisi dipengaruhi oleh kurang maksimalnya kinerja pengawas demikian pula kinerja pengawas sangat dipengarui oleh banyak faktor sepertilemahnya indikator pada kriteria desain, input dan proses supervisi sehingga supervisi belum efektif. Menurut Agus Dharma (2001: 2) menjelaskan bahwa supervisi yang efektif merupakan faktor penting untuk meningkatkan produktifitas kerja. Kegiatan supervisi yang dilakukan pengawas PAI merupakan bantuan yang sangat dibutuhkan oleh sekolah atau guru PAI agar pengelolaan kegiatan ekstrakurikuler PAI lebih berkualitas. Karena akan semakin baik pelaksanaan supervisi 
proses kegiatan ekstrakurikuler mulai dari penyusunan program, pembinaan, pemantauan, evaluasi dan pelaporan hasil supervisi yang dilakukan oleh pengawas PAI sebagai mana diamanahkan PMA No 12 Tahun 2012 pasal 4 maka akan semakin baik pula kualitilas proses ekstrakurikuler PAI.

\section{SIMPULAN}

DAN

\section{REKOMENDASI}

Berdasarkan pada hasil penelitian pelaksanaan supervisi ekstrakurikuler PAI pada SMP di Kecamatan Kokap dan Panjatan Kabupaten Kulon Progo dapat disimpulkan sebagai berikut :

Terdapat kesenjangan atau ketidak sesuaian padasetiap indikator kriteria desain, input, proses dan hasil supervisi ekstrakurikuler PAI, secara umum terdapat ketidak sesuaian antara program supervisi dengan realitas pelaksanaan supervisi dilapangan diukur dari pedoman kinerja pengawas. Pelaksanaan supervisi ekstrakurikuler PAIbelum maksimal dilihat dari indikasi tujuan supervisi yang belum tercapai, yakni belum semua guru membuat program dan melaksanakan ekstrakurikuler PAI.

Selanjutnya dapat direkomendasikan hal-hal sebagai berikut, (1) Pelaksanaan supervisi Ekstrakurikuler PAI hendaknya memperhatikan dan melaksanakan indikator-indikator pada program supervisi ekstarurikuler PAI, (2). Pemerintah dalam hal ini Kantor Kementerian Agama Kabupaten
Kulon Progo hendaknya selalu melakukanpembinaan pengelolaan komprehensip dan terstruktur, (3).Kepada peneliti lain diharapkan melakukan penelitian pada sasaran yang lebih luas agar dapat dijadikan pemetaan kualitas pelaksanaan program supervisi ekstrakurikuler PAI.

\section{DAFTAR PUSTAKA}

Suharsimi Arikunto, dan Cepi Safrudin Abdul Jabar. 2010. Evaluasi Program Pendidikan: Pedoman Teoritis Praktis Bagi Mahasiswa dan Praktisi Pendidikan. Edisi kedua. Jakarta: Bumi Aksara.

Burhan Bungin,. 2008.Penelitian Kualitatif : Komunikasi, Ekonomi, Kebijakan Publik, dan Ilmu Solial Lainnya. Jakarta: Kencana Pradana Media Group.

John W Cresswell,. 2013. Research Design : Pendekatan kualitatiff, Kuantitatif, dan Mixed, Terj. Oleh Achmad Fawaid. Yogyakarta: Pustaka Pelajar.

Agus Darma,. 2001. Manajemen Supervisi: Petunjuk Praktis Bagi Para Supervisor. Jakarta: PT Grafindo Persada.

Wahyu Imawati, 2014, Evaluasi Supervisi Akademik dalam Meningkatkan Kompetensi Pedagogik Guru PAI SMK Kabupaten Kulon Progo. Tesis MSI UMY. Yogyakarta.: 
Program Studi Supervisi Pendidikan Agama Islam.

Kementerian Agama R.I. 2012. Panduan Umum

Penyelenggaraan Kegiatan Ekstrakurikuler PAI Sekolah Menengah Pertama. Jakarta: Dirjen Pendis Direktorat PAI.

2011. Keputusan Menteri Agama R.I. Nomor 211 Tahun 2011 tentang Standar Nasional Pendidikan Agama Islam. Bab III Nomor $f$

$\begin{array}{lc}\text {----. 2009. Peraturan Direktur } \\ \text { Jendral } & \text { Pendidikan Islam } \\ \text { Nomor Dj.I/12A Tahun 2009 } \\ \text { tentang } & \text { Penyelenggaraan } \\ \text { Kegiatan } & \text { Ekstrakurikuler } \\ \text { Pendidikan Agama Islam pada } \\ \text { Sekolah. Dirjen Pendis } \\ \text { Kemenag, Jakarta. }\end{array}$
--------. 2012. Peraturan Menteri Agama R.I. Nomor 2 Tahun 2012 tentang Pengawas Madrasah dan Pengawas PAI di Sekolah. Bab II pasal 4 ayat 2.
---------. 2010 Peraturan Menteri Agama R.I. Nomor 16 Tahun 2010 tentang Pengelolaan Pendidikan Agamadan Pendidikan Keagamaan di Sekolah. Bab IV Pasal 8 ayat (3).

Kementerian Peraturan Menteri Pendayagunaan Aparatur Negara dan Reformasi Birokrasi. 2010. Peraturan Menteri nomor 21 tahun 2010 tentang jabatan fungsional pengawas sekolah dan angka kreditnya. Bab II pasal 6 ayat $2 b$.

Binti Maunah,. 2009. Supervisi Pendidikan Islam (Teori dan Praktik). Yogyakarta: Teras.

M.B. Miles \& A.M. Huberman. 1992. Analisis Data kualitatif terjemahan Tjetjeb Rohendi Rohidi. Jakarta: Penerbit Universitas Indonesia.

Pawito. 2007. Penelitian Komunikasi Kualitatif.Yogyakarta.: PT. LkiS Pelangi Aksara.

Piet Sahertian,. 2000. Konsep Dasar dan Teknik Supervisi Pendidikan. Jakarta: PT. Rineka Cipta. 